\title{
ASSESSING AND IMPROVING VOCATIONAL TEACHERS' EDUCATION AND TRAINING IN UKRAINE
}

\author{
Svitlana Tsymbaliuk, Tetiana Shkoda (Corresponding author), Maryna Artiushyna \\ Kyiv National Economic University named after Vadym Hetman, Kyiv, Ukraine \\ tnshkoda@ukr.net
}

\begin{abstract}
The aim of the research is to measure interrelation between VET quality and the level of teachers' education and training and to identify directions for their improving. The working hypothesis of the research is the assumption that education and training of graduates from colleges (specialists) will be of high quality if competencies are developed in accordance with the employers' demands. The working hypothesis was verified through a quantitative research (a sociological survey). The target group of the survey is 350 managers of financial and insurance companies in Ukraine, including human resources managers. The research has shown that the education and training of graduates from colleges do not adequately meet the needs of the labour market, and therefore must be improved, in particular, towards the development of appropriate competencies in accordance with the employers' requirements. The interrelation between VET quality and the level of teachers' education and training has been partially confirmed. More than a third of the surveyed employers saw the link between them. Based on the result of research, it was found that employers were not satisfied with the quality of college graduates' education and training. The conducted research has demonstrated the contradiction between the vision of the education and training results in educational establishments and the employers' expectations. This confirms the importance of their systematic collaboration in developing educational and professional training programmes and study plans. The results of the research are recommended to be used during the development of educational and professional programmes and study plans.
\end{abstract}

Keywords: education and training quality; college graduates; VET teachers; competence-based approach; professional skills; soft skills.

\section{Introduction}

Digitalisation and virtualisation of all spheres of social and economic life of society and rapid development of technologies, as well as globalisation of markets, dictate new demands not only for knowledge and abilities, but also for professional and soft skills of hired employees. Knowledge, skills and qualities that provide significant competitive advantages to their owners in the labour market and to enterprises in the market of goods and services, are losing their relevance in the age of the innovative economy. Vocational and technical education in Ukraine should be focused not only on receiving basic knowledge and professional skills by students within the corresponding speciality, but also on developing soft skills for the purpose of acquiring competencies that meet the actual needs of the labour market.

Teachers of vocational education and training (VET teachers) can work in colleges that belong to both the higher education system and the vocational and technical education system of Ukraine. According to the Law of Ukraine "On Higher Education" as of 01.07.2014 № 1556-VII, a college is a higher education institution that performs innovative educational activities related to obtaining a bachelor's degree and / or a junior bachelor's degree, conducts applied research and / or creative artistic activity. A college also has the right, in accordance with the license, to provide a secondary, vocational (vocational and technical) and / or professional advanced education (Parliament of Ukraine, 2017). The status of a college is obtained by an educational institution (a structural unit of an educational institution), in which the licensed volume of preparation of applicants for higher education for a bachelor's degree and / or a junior bachelor's degree is not less than $30 \%$ of the total licensed amount.

Many modern studies are devoted to the VET issues, in particular, to the functioning of VET systems in different EU countries (Csíkos, Kovács, and Kereszty, 2018, Deissinger, 2004, Garcia de Fez and Solbes Monzo, 2016, Graf, 2016, Hébrard, 2013, Marhuenda Fluixá, 2012, Montaki, 2012, Serafini, 2018). In Ukraine, the most extensive recent studies devoted to the problems of functioning of the VET system are "Results of the qualifying phase of research on vocational education" (Radkevych and Atyushina, 2017), and "National report on the state and prospects of the development of education in Ukraine" (Kremen et al, 2017) in the part of assessing the state of VET.

A significant challenge is the need for large-scale assessments of VET in Europe as a whole (Winther and Klotz, 2013) and in particular in Ukraine. Also, researchers emphasise the heterogeneity of the content of VET (Moodie, 2002) not only depending on the country (Baethge, Arends, and Winther, 2009), but also on the specifics of definite jobs (Billett, 2006). In order to resolve this contradiction, international agreements, recommendations (EU 2018/0008 (NLE)) and regulations intended to implement uniform competence standards have been concluded.

According to the authors, the education and training quality of graduates from colleges can be provided through the prism of the formation of competencies that should be possessed by these specialists in modern

Tsymbaliuk, S., Shkoda, T., \& Artiushyna, M. (2019). Assessing and improving vocational teachers' education and training in Ukraine. Advanced Education, 13, 70-80. DOI: 10.20535/2410-8286.153575 
economic conditions. This position is confirmed by a number of researchers on education and training quality (Akareem and Hossain, 2016, Grollmann, 2008, Iesina, 2012, Walker, 2008).

Many studies applicable to our research were devoted to various types of competencies of graduates of VET institutions within the context of improving education and training of graduates from colleges on the basis of a competence-based approach: social competencies (Monnier et al, 2016), economic-civic competence (Schumann et al, 2017) and vocational competencies (Winther and Klotz, 2013) etc.

Competencies are necessary for graduates from colleges to fulfil complex employers' demands and tasks. They involve not only knowledge and skills, but also contain the strategies and routines needed to apply knowledge and skills, as well as appropriate emotions and attitudes, and effective management of these components (Rychen and Salganik, 2000).

Taking into account the results of the comparative analysis of competencies and skills (Thanikachalam, 2016, Chinotti, 2015, Cinque, 2016, Rychen and Salganik, 2000), the authors believe that the most optimal approach for research is assessing the education and training quality by means of analysing professional skills and soft skills.

Current research is focused on the issues of VET teachers' professional development within modern society development. In particular, Day (2017) investigated competence-based education and VET teachers professional development; Runhaar, Bednall, Sanders and Yang (2016) studied issues of promoting VET teachers' innovative behaviour; Oser, Salzmann and Heinzer (2009) and Arifin, Rasdi, Anuar and Omar (2017) investigated different aspects of measuring competencies of VET teachers; Nickolaus (2007) studied the impact of teachers' competencies on the quality of VET; Fortmüller and Kramer (2014) proved the intermediate correlation between social competence of the VET teachers and their perception of working relations with students as the social burden, etc.

However, an adaptation of the system of teachers' education and training to the current needs of the labour market and the actual demands of employers in Ukraine remains an issue and is yet to be worked out. In this context, it is necessary to pay attention to the experience of such highly-developed countries as Germany and Switzerland, where such stakeholders as employers, besides governments, are crucially involved in the system at the topical reform discourse and measures taken in the two countries (Deissinger and Gonon, 2016).

Also, there is a lack of systematic studies on the changes that take place in the labour market in Ukraine despite the fact that a large number of studies devoted to the labour market have already been published (Horbal, Shpak and Shpak, 2016, Koettl et al, 2014, Kupets, 2014; Libanova et al, 2014, Lukyanenko and Oliskevych, 2014, Petrova, 2016; Petyuh, Shchetinina and Shkoda, 2016). In particular, it relates to researching employers' needs for competencies of graduates from colleges under current economic conditions.

The matter of ensuring the quality of education and training for graduates from colleges is directly connected with developing the competencies, which are necessary for the labour market. Professional skills and soft skills are the most important competencies. The process of developing competencies must be wellbalanced, reflected in the teaching content and technologies.

The aim of this research is to measure interrelation between VET quality and the level of teachers' education and training and to identify directions for their improving.

The formulated aim of this research can be achieved through solving the following tasks:

- assessing the education and training quality of college graduates (specialists) by means of a survey of employers;

- evaluating the level of the college graduates' professional skills and soft skills development;

- assessing business interests and recognising the opportunities and areas for cooperation between educational institutions and business companies to improve the quality of education and training of specialists (graduates from colleges);

- identifying the directions for improving the education and training of graduates from colleges (specialists), as well as VET teachers in order to adapt them to the needs of the labour market and the demands of employers.

The working hypothesis of the research is the assumption that education and training of graduates from colleges (specialists) will be of high quality if relevant competencies are developed in accordance with the employers' demands as well as the teachers' education and training provides forming these competences in students. 


\section{Methods}

In order to confirm or disprove the working hypothesis, the authors have conducted a quantitative research (a survey) in cooperation with the representatives of the Institute of Professional Qualifications (Kyiv, Ukraine) during 2017-2018.

The target group of the survey is Ukrainian financial and insurance companies. The number of enterprises belonging to financial and insurance activity in Ukraine was 3,887 as of the end of 2016, according to the data of the State Statistics Service of Ukraine (2016b).

Due to the large volume of the general population, a simple random sample type was chosen as the relative homogeneity of units for the general population.

Data on the sample required for the general population of $\mathrm{N}=3887$ persons and $5 \%$ accuracy is provided in Table 1.

Table 1. Data on the sample required for the general population of $N=3887$ persons and $5 \%$ accuracy

\begin{tabular}{|l|c|}
\hline \multicolumn{1}{|c|}{ Indicator } & Value \\
\hline Trust probability & $95 \%$ \\
\hline Trust interval & $\pm 5 \%$ \\
\hline General population & 3887 \\
\hline Required sample size & 350 \\
\hline
\end{tabular}

The sample size for $5 \%$ accuracy is 350 people. The survey was undertaken by 350 managers, including human resources managers, from financial and insurance companies. So, the survey was representative. Among respondents, there were representatives of various gender and age groups. The respondents' educational level: 322 - master's degree, 23 - bachelor's degree, 5 - Ph.D.

To organise the survey a special questionnaire was developed. The questionnaire was sent to the respondents by e-mail. The respondents filled in the questionnaire by themselves. In case of questions, the respondents could ask the researchers via e-mail.

Participation in the survey was voluntary and the respondents might stop participation at any time. Collecting and storing data was accurate and protected from loss. The privacy of the respondents was kept.

The questionnaire contained 14 questions. Questions were divided into 5 blocks:

I. Information about a respondent.

II. Information about a company.

III. Questions for determining the level of professional skills and soft skills required by graduates from colleges (specialists) - questions 1-4, 6, 7.

IV. Questions for assessing the education and training quality of graduates from colleges (specialists) questions 5, 8, 9 .

V. Questions on the assessment of the companies' willingness and readiness to cooperate with educational establishments (colleges, universities) - questions 10-14.

Questionnaire combined closed-ended and open-ended questions. The numerical scale (from 0 to $100 \%$ ), where $0 \%$ corresponds to the lowest rating, $100 \%$ - to the highest, was used to assess the education and training quality of graduates from colleges by respondents.

Processing of the survey results was made using MS Excel. The analysis of the respondents' assessment of the education and training quality of graduates from colleges (specialists) was carried out on the basis of the following statistical indicators - average (arithmetic average, median, mode), coefficients of variation and asymmetry, excesses, etc.

The coefficient of variation was calculated by the formula

$$
\mathrm{V}_{\sigma}=\frac{\sigma}{\overline{\mathrm{x}}} \cdot 100 \%
$$

where $\sigma$ - means square (standard) deviation;

$\overline{\mathrm{X}}$ - arithmetic average value.

The method of ranking was used to determine professional and soft skills that graduates from colleges have to possess. Respondents were asked to choose the five most important professional skills and soft skills based on their opinion and rank them. 


\section{Results}

The first task of the research was to assess education and training quality of graduates from colleges (specialists) by means of an employer survey. The results of the statistical analysis of the respondents' assessment are provided in Table 2. The coefficient of variation is $26.7 \%$ (less than 33\%). It indicates that the assessments of the managers who participated in the survey are homogeneous.

Table 2. Statistical indicators of the respondents' assessment of the education and training quality of graduates from colleges

\begin{tabular}{|l|c|}
\hline \multicolumn{1}{|c|}{ Statistical indicators } & Value \\
\hline Arithmetic average & 52.8 \\
\hline Standard error & 0.75 \\
\hline Median & 50 \\
\hline Mode & 60 \\
\hline Standard deviation & 14.1 \\
\hline Sample dispersion & 198.57 \\
\hline Excess & 0.82 \\
\hline Asymmetry & -0.13 \\
\hline Interval & 70 \\
\hline Minimum & 20 \\
\hline Maximum & 90 \\
\hline Total & 18490 \\
\hline Score & 350 \\
\hline
\end{tabular}

The asymmetry coefficient has a negative value (see Table 2) and less (by module) than 0.25 (|A| $<0.25$ ), which indicates a left-sided low asymmetry in the distribution of managers' assessment of the education and training quality of graduates from colleges.

A positive value of the excess $\left(E_{k}>0\right)$ indicates that the distribution is more peaked than normal.

Distribution of respondents based on the assessment of the education and training quality of graduates from colleges is presented in Fig. 1. For assessing the education and training quality of graduates from colleges by respondents there were used the numerical scale, where $0 \%$ corresponds to the lowest rating, $100 \%$ - to the highest.

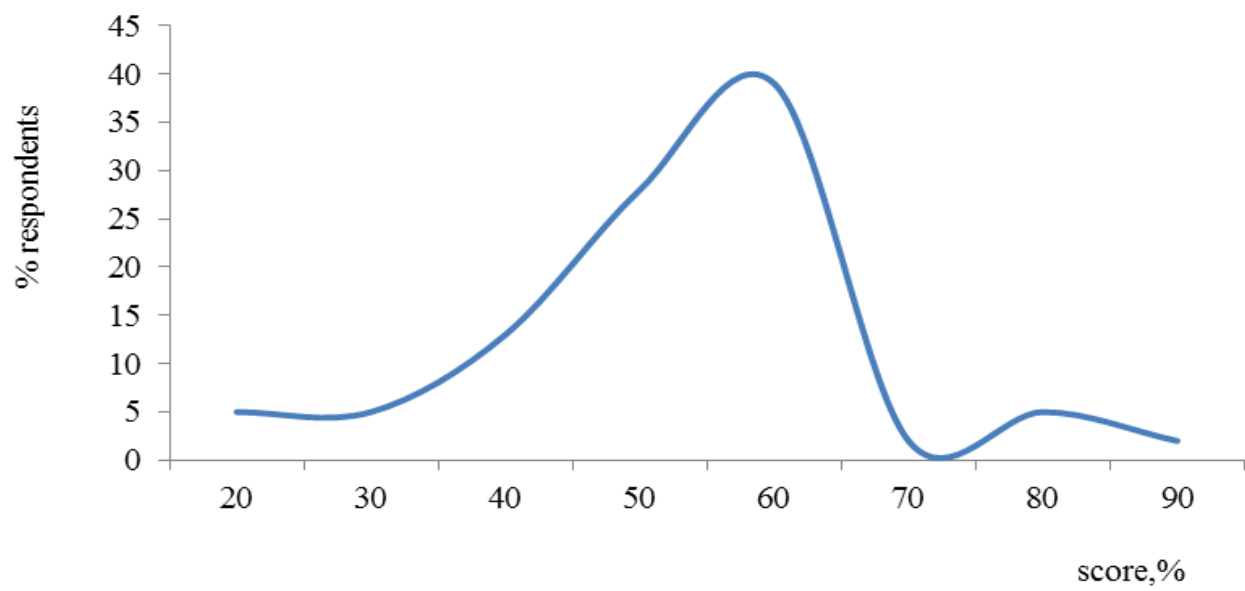

\section{Figure 1. Distribution of respondents based on the assessment of the education and training quality of graduates from colleges.}

Consequently, the results of the survey point out low statistical indicators of respondents' assessment of the education and training quality of graduates from colleges. According to the assessment of the education and training quality of graduates from colleges, the assessment of the managers who participated in the survey is homogeneous. 
The above results have confirmed the need for improving the system of education and training for graduates from colleges (specialists) in accordance with the current needs of the labour market and the actual demands of employers.

The second task of the research was the determination of the required level of the professional skills and soft skills development that graduates from colleges (specialists) have to possess.

Distribution of the answers of the respondents to the question "Determine the level of professional skills required by graduates from colleges (specialists)" is shown in Fig. 2.

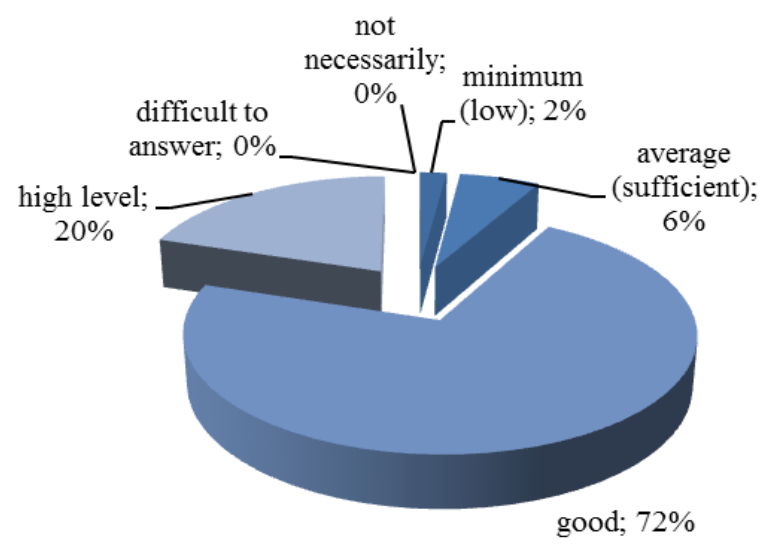

Figure 2. Distribution of answers to the question "Determine the level of professional skills
required by graduates from colleges (specialists)".

According to the results of the survey (Fig. 2), the overwhelming majority (92\%) of managers believe that the education and training system should provide a higher than average level of professional skills development.

Among the most important professional skills, which graduates from colleges (specialists) have to possess, respondents singled out the following (in order of decreasing significance): 1) Ability to find, systematise and analyse information; 2) Ability to organise certain types of work (depending on the scope of professional activity); 3) Ability to work in a team; 4) Ability to plan work; 5) Ability to make one's own decisions; 6) Ability to use information technologies; 7) Ability to accurately express one's own thoughts; 8) Time management skills; 9) Ability to adapt quickly to changes; 10) Ability to establish contact and readiness for dialogue.

The list of professional skills that graduates from colleges (specialists) lack according to respondents' point of view appeared to be somewhat different. The list contains: 1) Ability to accurately express one's own thoughts; 2) Time management skills; 3) Ability to plan work; 4) Ability to make one's own decisions; 5) Ability to listen; 6) Ability to find, systematise and analyse information.

Lack of such skills as the ability to accurately express one's own thoughts and the ability to listen is connected to the use of electronic means of communication by young people. Insufficient development of work planning and independent decision-making skills is due to the inadequate development level of autonomy and responsibility. Lack of the ability to find, systematise and analyse information primarily relates to the difficulty of the processing of large volumes of the information provided.

It should be noted that such professional skills as the ability to plan work, the ability to find, systematise and analyse information, the ability to accurately express one's own thoughts, the ability to make one's own decisions and time management skills are all included in the list of the most important and underdeveloped skills of graduates from colleges (specialists). In this regard the relevant educational programmes and curricula for the training of specialists should stipulate academic disciplines, workshops and training focused on the formation of the professional skills listed above.

Distribution of the answers of the respondents to the question "Determine the level of soft skills required by graduates from colleges (specialists)" is shown in Fig. 3. 


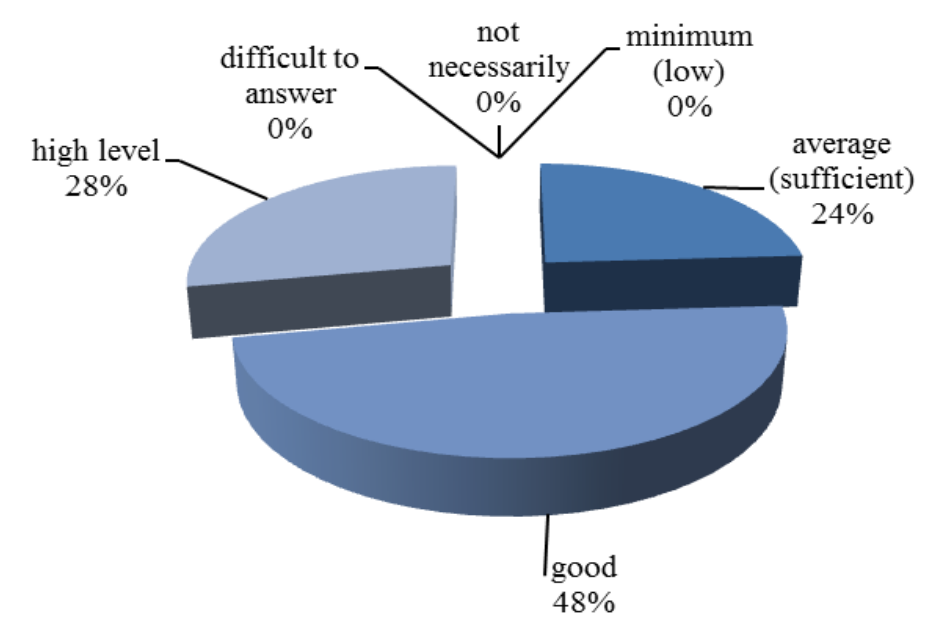

Figure 3. Distribution of the answers to the question "Determine the level of soft skills required by graduates from colleges (specialists)".

Answering the question about the level of the soft skills development necessary for graduates from colleges (specialists), $48 \%$ of respondents chose a good level, $28 \%$ - high level and $24 \%$ - average level (Fig. 3). None of the respondents have indicated a low development level of soft skills.

According to the respondents, the most important soft skills that graduates from colleges have to possess (in order of decreasing significance) are the following: 1) Responsibility; 2) Orientation towards results; 3) Desire for learning and development; 4) Diligence; 5) Purposefulness (striving to achieve set goals); 6) Proactivity; 7) Analytical skills; 8) Communication skills; 9) Organisational skills; 10) Creativity.

According to the respondents, the list of soft skills that graduates from colleges (specialists) are lacking includes: 1) Responsibility; 2) Stress resistance; 3) Communication skills; 4) Self-discipline and strictness to others; 5) Honesty and fairness; 6) Orientation towards results.

The lack of soft and professional skills of graduates from colleges is due to an inadequate level of personal communication, autonomy and responsibility. Such characteristics as responsibility, orientation towards results and communication skills are among the most important and underdeveloped skills of graduates from colleges (specialists).

Distribution of answers of respondents to the question "Do you think that the lack of development of professional skills and soft skills is due to inadequate education and training quality?" is the following: $10 \%$ of the answers "yes"; $64 \%$ of the answers "rather yes than no"; $22 \%$ - difficult to answer; $2 \%$ - rather no than yes; $2 \%$ - no. As it can be seen, the majority of respondents (74\%) believe that insufficient development of professional skills and soft skills is due to the insufficient quality of education and training of specialists. It also confirms the need to improve the system of education and training of specialists in accordance with the current needs of the labour market and the actual demands of employers.

Distribution of the answers of the respondents to the question "Do you consider that the insufficient level of specialists' knowledge and skills is due to the inappropriate quality of teachers' education and training?" is the following: $10 \%$ of the answers "yes"; $28 \%$ of the answers "rather yes than no"; $50 \%$ - difficult to answer; $12 \%$ - rather no than yes; $0 \%$ - no. According to these results of the survey, half of the respondents had a difficulty in answering this question. 38\% of the respondents indicated that there was a correlation between the quality of education and training of specialists - graduates from colleges and the quality of education and training of VET teachers. None of the respondents vehemently denied the existence of such a link.

Consequently, the education and training of teachers, who possess the necessary competencies (in accordance with the needs of the labour market and demands of employers), as well as educational technologies that allow students to form and develop the necessary competences, contribute to the improvement of the quality of education and training of graduates from colleges.

The third task of the research was the assessment of business interests and identification of opportunities and areas for cooperation between educational institutions and business companies in respect of improving the quality of education and training of specialists (graduates from colleges).

$72 \%$ of the respondents gave a positive answer to the question "Does your company cooperate with educational institutions (colleges, universities)?" $100 \%$ of the respondents, who answered that their company cooperates with educational institutions, indicated that the company organised internships for students from colleges and universities. 
Distribution of the answers of the respondents to the question "Are you ready to cooperate with universities in organising on-the-job internships for students - future VET teachers?" is the following: 20\% of the answers "yes"; $40 \%$ of the answers "rather yes than no"; $12 \%$ - difficult to answer; $6 \%$ - rather no than yes; $22 \%$ - no. It shows that $60 \%$ of the respondents indicated that they were ready to provide jobs and organise internships at enterprises for students - future VET teachers. In the authors' opinion, this is a rather a high indicator.

Regarding the readiness of companies to participate in the development of a study plan, business representatives demonstrated an average readiness $(54 \%)$ for preparation of a study plan for the education and training of specialists (graduates from colleges) (Fig. 4) and low readiness (42\%) for preparation of a study plan for the education and training of future teachers (Fig. 5).

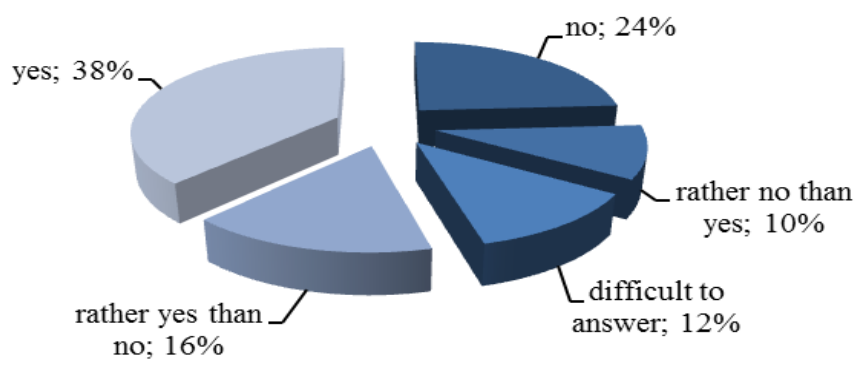

Figure 4. Distribution of the answers to the question "Are you ready to cooperate with colleges on working out a study plan for education and training of specialists?”

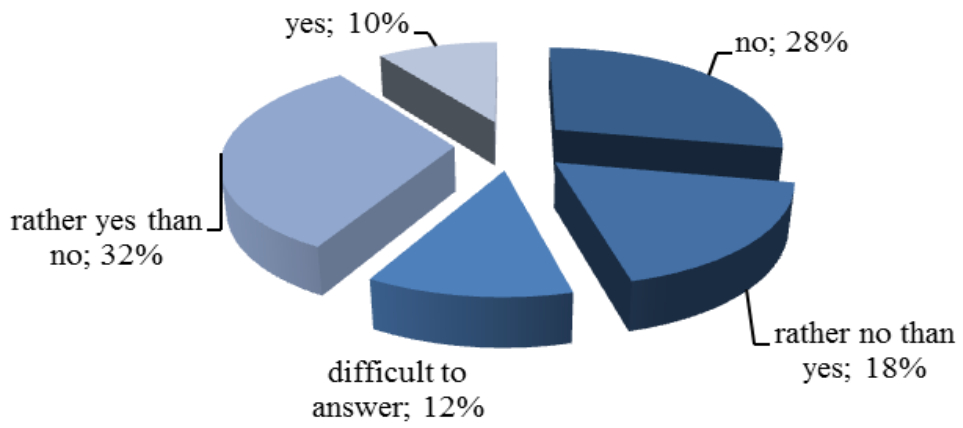

Figure 5. Distribution of the answers to the question "Are you ready to cooperate with universities on working out a study plan for future teachers' education and training?"

According to the authors' point of view, such a difference in the level of employers' interest in participating in the development of study plans for the education and training of specialists (graduates from colleges) (Fig. 4) and the future teachers' education and training (Fig. 5) is due to the fact that business representatives are more interested in raising the quality of graduates from colleges. In addition, a significant part of the respondents still do not see a strict correlation between the quality of the education and training of specialists - graduates from colleges and the quality of the education and training of teachers, as evidenced by the results of the research.

The results of the survey also gave opportunities to solve the fourth task - identification of directions for improving the training of graduates from colleges (specialists), as well as VET teachers in order to adapt it to the needs of the labour market and the demands of employers.

Based on the research, we can conclude that VET teachers should understand the significance of professional skills and soft skills for the successful work of future specialists (graduates from colleges) and 
the field of their practical use, on the one hand, and on the other hand, they should possess appropriate educational technologies to form and develop these skills amongst students.

The first task can be solved by means of undergoing on-the-job internships by students (future VET teachers). Only in such cases, future VET teachers can understand the real business needs for those competencies and specific features of certain activities.

In order to implement the results of the research at the Kyiv National Economic University named after Vadym Hetman, changes to the study plan of speciality 015 "Vocational Education (Economics)" have been made. The introduction of internships (in companies) at the Bachelor's and Master's educational levels is amongst these changes. According to the survey results, about $60 \%$ of the respondents are ready to organise internships (in companies) for future VET teachers.

The duration of the pedagogical practical training at the Bachelor's and Master's educational levels was increased and new disciplines in the form of practicum and training were implemented in order to solve the second task related to the education and training of students of the speciality 015 "Vocational Education (Economics)". A practicum is considered as a graduate-level course, often in a specialised field of study, that is designed to give students supervised practical application of a previously or concurrently studied theory (Educalingo 2018).

It was necessary for future VET teachers to master the relevant educational technologies for the formation and development of appropriate competencies amongst students of colleges and students of vocational schools. For this purpose at the Bachelor's educational level the following new disciplines were implemented in the form of practicums and training - Educational Management Practicum, Innovative Technologies in Education Practicum, Self-Management Practicum, Information Technologies in Education and TMT Practicum, Teaching Techniques of General Economic Disciplines Practicum, Teaching Methods of Professional Direction Disciplines Practicum, Training in Management of Social and Psychological Processes in Professional Activities, Training in Proficiency of Decision Making and Principles of SelfControl Training.

On the one hand, the indicated disciplines are aimed at the formation of professional and soft skills in students, which are the most in-demand by employers and, on the other hand, they are focused on training competencies for the development of these skills amongst students.

\section{Discussion}

Our research has shown that the education and training of graduates from colleges do not adequately meet the needs of the labour market, and therefore must be improved, in particular, towards the development of appropriate competencies in accordance with the employers' requirements. The interrelation between VET quality and the level of teachers' education and training has been partially confirmed. More than a third of the surveyed employers saw the link between them.

Based on our research, we found that employers are not satisfied with the quality of college graduates' education and training. In their view, the VET system should provide a higher level of development of such professional skills as the ability to plan work, the ability to find, organise and analyse information, the ability to accurately express one's own thoughts, time management and decision-making skills. Employers' satisfaction with the development of soft skills of graduates from colleges is greater. At the same time, characteristics such as responsibility, results orientation and communication skills are recognised as one of the most important and underdeveloped skills of graduates from colleges (specialists).

The conducted research has once again demonstrated the contradiction between the vision of the results of the education and training of future specialists in educational establishments and the employers' expectations. This confirms the importance of their systematic collaboration in developing educational and professional training programmes and study plans. Promising is the organisation of various forms of practical activity and internships of future and actual VET teachers, students of VET establishments in companies. It is important the regular exchange of experience on the topical issues of the organisation of education and training in colleges and the identification of the needs for change in order to bring the level of education and training of future specialists closer to the urgent requirements of the economy.

The obtained results do not differ significantly from the results of similar studies. In particular, in 2012 the Kyiv International Institute of Sociology within the framework of the project "The rating of Ukraine's higher educational institution "Compass-2012" conducted a study of graduates and employers on various aspects of higher education establishments, employment experience, professional skills and competences of graduates (Kashyn, Polshchykova \& Sakhno, 2012). According to the survey of employers, it has been found that the most important qualities of employees are practical skills, the ability to solve problems and customer service skills. A particularly serious problem was the lack of soft skills in graduates: communication skills, 
the ability to present, negotiate, emotional control. The representatives of companies also noted the need for the development of mental skills of applicants - creativity, the ability to analyse information, systematic thinking, etc. In our study employers paid more attention to the analytical skills of specialists, their ability to manage time, decision-making and personal responsibility. We believe that it should be given more attention to these qualities in education and training.

The main limitation of the study is the focus on Ukrainian financial and insurance companies. Also, certain limitations are related to the use of a quantitative research. Further research should be devoted to estimating the quality of education and training of students obtaining Bachelor's educational level on speciality 015 "Vocational Education (Economics)" after changes made in study plans and in the content of internships. It is important to determine students' readiness to the teaching profession and implementation educational innovations in their future teaching activities.

From the scientific point of view, further research should be focused on professional skills and soft skills that specialists in various professional training spheres have to possess, as well as identification of pedagogical conditions, forms and educational technologies to form and develop these skills among students. From the practical point of view, it is important to study whether improvements of VET teachers' education help to form necessary competencies among students.

\section{Conclusions}

The Ukrainian labour market requires qualitatively educated and trained specialists - graduates from colleges. The formation of competencies that should be possessed by these specialists in modern economic conditions is considered by the authors as the way of improving their education and training. It is confirmed by a number of researchers of education and training quality problematic. The working hypothesis in this pedagogical research was verified with the help of sociological survey toolkit.

The research results confirmed the authors' hypothesis that education and training of college graduates (specialists) will be of high quality if it develops relevant competencies in accordance with the employers' demands as well as the teachers' education and training provides forming these competences in students.

The results of the research promoted the implementation of changes in the study plan of speciality 015 "Vocational Education (Economics)" at the KNEU. The duration of the pedagogical practical training was increased and new disciplines in the form of practicum and training were implemented. The new disciplines are aimed at the formation of professional and soft skills in students, which are the most in-demand by employers, and they are focused on training competencies for the development of these skills amongst students as well.

The obtained results testify to the need for systematic monitoring of the labour market, the survey of employers on the actual needs of graduates' professional competencies and the corresponding modernisation of study plans and training programmes. Particular attention is also needed for the cooperation of employers with establishments of higher education, which train VET teachers.

\section{Acknowledgement}

The materials of the article are based on the outcomes of the implementation of the Erasmus+ project "Improving teacher education for applied learning in the field of VET (ITE-VET)" (2016-2018) № 574124EPP-1-2016-1-DE-EPPKA2-CBHE-JP (wiwi.uni.kn/ite-vet). This publication reflects the views only of the authors, and the Commission cannot be held responsible for any use which may be made of the information contained therein.

The materials of the article are also further developed in the context of social competence of future VET teachers within the OeAD Scholarship research project "Social competence in education and training of future VET teachers. An empirical comparative study comparing Austria and Ukraine.” (February-July 2019).

\section{References:}

Akareem, H.S., \& Hossain, S.S. (2016). Determinants of education quality: what makes students' perception different? Open Review of Educational Research, 3 (1), 52-67. https://doi.org/10.1080/23265507.2016.1155167

Arifin, M.A., Rasdi, R.M., Anuar, M.A.M. \& Omar, M.Kh. (2017). Competencies of Vocational Teacher: A Personnel Measurement Framework. Paper presented at $4^{\text {th }}$ International Conference on Educational Research and Practice 2017. International Journal of Academic Research in Business and Social Sciences, 7, 147-164. http://dx.doi.org/10.6007/IJARBSS/v7-i14/3659

Baethge, M., Arends, L., \& Winther, E. (2009). International large-scale assessment on vocational and occupational education and training. In F. Oser, U. Renold, E.G. John, E. Winther, S. Weber (Eds.), VET boost: Towards a theory of professional competencies. Essays in honor of Frank Achtenhagen (pp.3-24). Rotterdam: Sense Publishers.

Billett, S. (2006). Work, change and workers. Springer: Dordrecht.

Chinotti, B. (2015). Hiring and Inspiring Graduates in the New Work Environment. Speech at "Soft Skills and their role in employability New perspectives in teaching, assessment and certification". Paper presented at the Workshop in Bertinoro, FC, Italy. 
Cinque, M. (2016). Lost in translation. Soft skills development in European countries. Tuning Journal for Higher Education, 3 (2), $389-427$. https://doi.org/10.18543/tjhe-3(2)-2016pp389-427

Csíkos, Cs., Kovács, Zs. \& Kereszty, O. (2018). Hungarian vocational education teachers' views on their pedagogical knowledge and the information sources suitable for their professional development. Empirical Research in Vocational Education and Training, 10 (2), 1-15. https://doi.org/10.1186/s40461-018-0063-x

Day, C. (2017). Competence-based Education and Teacher Professional Development. In M. Mulder (Ed.), Competence-based Vocational and Professional Education. Bridging the Worlds of Work and Education (pp.165-182). Springer, Cham.

Deissinger, T. (2004). Germany's system of vocational education and training: challenges and modernisation issues. International Journal of Training Research, 2 (1), 76-99. https://doi.org/10.5172/ijtr.2.1.76

Deissinger, T. \& Gonon, Ph. (2016). Stakeholders in the German and Swiss vocational educational and training system: Their role in innovating apprenticeships against the background of academisation. Education + Training, 58 (6), 568-577. https://doi.org/10.1108/ET-02-2016-0034

Educalingo. (2018). Practicum. Retrieved 23 June, 2018 from https://educalingo.com/en/dic-en/practicum

European Comission. (2018). Proposal for a COUNCIL RECOMMENDATION on Key Competences for Lifelong Learning, 2018/0008 (NLE). Retrieved 12 April, 2018 from https://ec.europa.eu/education/sites/education/files/recommendation-key-competenceslifelong-learning.pdf

Fortmüller, R., \& Kramer, D. (2014). Soziale Kompetenzen und soziale Belastungen - Eine empirische Studie zum Zusammenhang zwischen den sozialen Kompetenzen und den sozialen Belastungen von Wirtschaftslehrer/innen [Social skills and social burdens an empirical study on the relationship between social skills and social burdens of economics teachers.]. Wissenplus Wissenschaftplus, 32 (3), 6-8. Retrieved 28 June, 2018 from https://fdokument.com/document/soziale-kompetenzen-und-sozialebelastungen.html

García de Fez, S., \& Solbes Monzó, J.R. (2016). School Management Teams in Spain’s Professional Education: a Continuous Education Proposal. Revista Iberoamericana de Educación, 70, 161-182. Retrieved 25 June, 2018 from https://rieoei.org/RIE/issue/view/8/13

Graf, L. (2016). The rise of work-based academic education in Austria, Germany and Switzerland. Journal of Vocational Education \& Training, 68 (1), 1-16. https://doi.org/10.1080/13636820.2015.1107749

Grollmann, Ph. (2008). The Quality of Vocational Teachers: teacher education, institutional roles and professional reality. European Educational Research Journal, 7 (4), 535-547. https://doi.org/10.2304/eerj.2008.7.4.535

Hébrard, P. (2013). Ambiguities and paradoxes in a competence-based approach to vocational education and training in France. European Journal for Research on the Education and Learning of Adults, 4 (2), 111-127. https://doi.org/10.3384/rela.2000-7426.rela9002

Horbal, N., Shpak, M. \& Shpak, Y. (2016). Double-sided analysis of the labor market in Ukraine: graduates' and employers' view. An International Quarterly Journal, 5 (1), 27-34. Retrieved 25 June, 2018 from http://ena.lp.edu.ua/bitstream/ntb/33088/1/04-2734.pdf

Iesina, O. (2012). Kryterii otsinky jakosti pidgotovky suchasnykh fakhivtsiv [Criteria for assessing the quality of today's professionals]. Teoria ta metodyka navchannia fundamentalnykh dystsyplin $u$ vyshchij shkoli, 7, 84-90..Retrieved 02 April, 2018 from http://dspace.oneu.edu.ua/jspui/handle/123456789/1401

Kashyn, A., Polshchykova, Ye. \& Sakhno, Yu. (2012). Graduates of Ukrainian higher education establishments by the eyes of employers. Report. Retrieved 28 March, 2019 from http://www.yourcompass.org/docs/Employees\%20on\%20University_Graduates.pdf

Koettl, J., Kupets, O., Olefir, A., \& Santos, I. (2014). In Search of Opportunities? The Barriers to More Efficient Internal Labor Mobility in Ukraine. IZA Discussion Papers, No. 8631. Retrieved 31 March, 2018 from https://www.econstor.eu/bitstream/ 10419/106573/1/dp8631.pdf

Kupets, O. (2014). Labor Market Challenges of Aging and Shrinking Population in Ukraine. The Journal of Comparative Economic Studies, 9, 99-134. Retrieved 25 June, 2018 from http://www.ces.kier.kyoto-u.ac.jp/jces/09_jces_2014/08_Kupets.pdf

Libanova, E., Cymbal, A., Lisogor, L., Marchenko, I., and Iarosh, O. (2014). Labour market transitions of young women and men in Ukraine. Youth Employment Programme, Employment Policy Department. Geneva, ILO, Work4Youth publication series, No.11. Retrieved 31 March, 2018 from International Labour Office website http://www.ilo.org/wcmsp5/groups/public/---dgreports/--dcomm/documents/publication/wcms_242916.pdf

Lukyanenko, I. \& Oliskevych, M. (2014). Labour market in Ukraine: an empirical dynamic analysis using error correction model. Bulletin of Taras Shevchenko National University of Kyiv. Economics, 6 (159), 52-58. Retrieved 25 June, 2018 from http://bulletineconom.univ.kiev.ua/wp-content/uploads/2015/11/159_52-58.pdf

Marhuenda Fluixá, F. (2012). La Formación Profesional. Logros y retos [Vocational Education. Achievements and challenges]. Madrid: Síntesis, D.L.

Moodie, G. (2002). Identifying vocational education and training. Journal of Vocational Education \& Training, 54 (2), $249-266$. https://doi.org/10.1080/13636820200200197

Montaki, S. (2012). The contribution of vocational education and training in the preservation and diffusion of cultural heritage in Greece: the case of the specialty "Guardian of museums and archaeological sites". International Journal of Humanities and Social Science, 2 (24), 51-58. Retrieved 25 June, 2018 from http://www.ijhssnet.com/journals/Vol_2_No_24_Special_Issue_December_2012/8.pdf

Kremen, V. (Ed) (2017). National Report on the State and Prospects of Education Development in Ukraine. National Academy of Educational Sciences of Ukraine. Kyiv, Pedahohichna dumka.

Oser, F., Salzmann, P., \& Heinzer, S. (2009). Measuring the competence-quality of vocational teachers: An advocatory approach. Empirical Research in Vocational Education and Training, 1(1), 65-83. Retrieved 26 June, 2018 from https://www.pedocs.de/volltexte/2012/5158/pdf/ERVET_2009_1_Oser_et_al_Measuring_the_competence_quality_of_voc ational_teachers_D_A.pdf

Nickolaus, R. (2007). Qualität in der beruflichen Bildung [Quality in vocational education]. Zeitschrift für Berufs- und Wirtschaftspädagogik (ZBW), 103(2), 161-166. Retrieved 26 June, 2018 from https://www.pedocs.de/volltexte/2010/2102/pdf/Nickolaus_Qualitaet_in_der_beruflichen_Bildung_2009_D_A.pdf

Parliament of Ukraine. (2017). Law of Ukraine “About higher education” as of 01.07.2014 № 1556-VII with last changes and additions as of 20.12.2017. Retrieved 02 April, 2018 from http://zakon5.rada.gov.ua/laws/show/1556-18 
Petrova, I. (2016). Suchasni osoblyvosti rozvytku rynku pratsi Ukrainy [Modern features of the Ukrainian labor market development]. In: I. Petrova \& V. Blyzniuk (Eds.), Rozvytok sotsialno-trudovoi sfery Ukrainy: teoria, praktyka, perspektyvy [Development of the social and labor sphere of Ukraine: theory, practice, perspectives] (pp. 117-130). Kyiv, Ukraine: Institute for Economics and Forecasting of NAS of Ukraine.

Petyuh, V., Shchetinina, L. \& Shkoda, T. (2017). Development trends, asymmetries and impact factors of youth employment in Ukraine. Problemy Polityki Spotecznej. Studia i Dyskusje, 1(36), 27-42. Retrieved 26 June, 2018 from http://www.problemypolitykispolecznej.pl/images/czasopisma/36/PPS-36-27-42.pdf

Radkevych, V., \& Atyushina, M., eds. (2017). Vocational education: informational and analytical materials on the results of the qualifying phase of research. IVE of NAPS of Ukraine, Kyiv.

Runhaar, P., Bednall, T., Sanders, K., \& Yang, H. (2016). Promoting VET teachers' innovative behaviour: exploring the roles of task interdependence, learning goal orientation and occupational self-efficacy. Journal of Vocational Education \& Training, 68(4), 436-452. https://doi.org/10.1080/13636820.2016.1231215

Rychen, D.S., \& Salganik, L.H. (2000). Definition and Selection of Key Competencies: Theoretical and Conceptual Foundations. In Fourth General Assembly of the OECD Education Indicators Programme, The INES Compedium, Contributions from the INES Networks and Working Groups (pp. 61-73). Tokyo, Japan: OECD. Retrieved 26 June, 2018 from http://www.edu.uszeged.hu/ csapo/publ/OECD_GA4.pdf

Serafini, M. (2018). The professional development of VET teachers in Italy: participation, needs and barriers. Statistical qualifications and benchmarking in an international perpective. Empirical Research in Vocational Education and Training, 10(3), 1-15. https://doi.org/10.1186/s40461-018-0064-9

State Statistical Service of Ukraine. (2016a). Vocational and technical education establishments. Higher education establisments of III accreditation levels. Retrieved 02 April, 2018 from http://www.ukrstat.gov.ua

State Statistical Service of Ukraine. (2016b). Number of business entities by types of economic activity in 2016. Retrieved 02 April, 2018 from http://www.ukrstat.gov.ua

Thanikachalam, V. (2016). Enhancing Professional and Soft Skills of the Indian Engineering Graduates. Journal of Engineering \& Technology Education, 10(2), 1-17. Retrieved 26 June, 2018 from http://www.ifees.net/wp-content/uploads/2017/03/PaperNITTTR-CH-Journal.pdf

Walker, P. (2008). What do students think they (should) learn at college? Student perceptions of essential learning outcomes. Journal of the Scholarship of Teaching and Learning, 8(1), 45-60. Retrieved 26 June, 2018 from https://www.iupui.edu/ josotl/archive/vol_8/no_1/v8n1walker.pdf

Winther, E., \& Klotz, V.K. (2013). Measurement of vocational competences: an analysis of the structure and reliability of current assessment practices in economic domains. Empirical Research in Vocational Education and Training, 5(2), 1-12 https://doi.org/10.1186/1877-6345-5-2

Received: January 03, 2019

Accepted: November 19, 2019 